\title{
Intrahepatic cholestasis and cutaneous bullae associated with glibenclamide therapy
}

\author{
V. WONGPAITOON \\ B.Sc., M.B., M.R.C.P. \\ R. I. RUSSELL \\ M.D., Ph.D., F.R.C.P.
}

Gastroenterology Unit, and Department of Pathology, Royal Infirmary, Glasgow G4 OSF

\begin{abstract}
Summary
Intrahepatic cholestasis and cutaneous bullae associated with glibenclamide therapy are described in a 61-year-old diabetic patient who presented with hypoglycaemic coma. These features have not previously been reported as side effects of glibenclamide therapy, but intrahepatic cholestasis may occur with chlorpropamide, a similar sulphonylurea agent. The mechanism of this cholestasis is not clear at present.
\end{abstract}

\section{Introduction}

Glibenclamide, a potent oral hypoglycaemic drug (Aumüller et al., 1966), has been considered to have fewer adverse effects than chlorpropamide which is an equivalent sulphonylurea agent. A diabetic patient presenting with hypoglycaemia is described who had reversible intrahepatic cholestasis and cutaneous bullae which appeared to have been induced by a $10 \mathrm{mg}$ dose of glibenclamide.

\section{Case history}

A 61-year-old man with a 17-month history of maturity-onset diabetes mellitus, retinopathy and mild proteinuria was admitted unconscious with a blood glucose of less than $1.5 \mathrm{mmol} / \mathrm{l}$. He had been treated with glibenclamide, initially $5 \mathrm{mg}$ daily, and increased to $10 \mathrm{mg}$ daily 5 months before admission. His other regular medication was digoxin $0.25 \mathrm{mg}$, frusemide $80 \mathrm{mg}$ and Slow-K $1800 \mathrm{mg}$ daily given for left ventricular failure due to ischaemic heart disease. He became gradually unwell with loss of appetite and drowsiness 3 weeks before admission. On admission he was in grade III coma without any localizing signs. There were 2 clear, colourless bullae $3 \mathrm{~cm}$ in diameter on the sole of the right foot and the right upper thigh. There was no evidence of inflammation around the bullae. He was also noted to be slightly jaundiced.
On investigation, he had a haemoglobin of 13. Sू $\mathrm{g} / \mathrm{dl}$, white blood cell count $10 \times 10^{9} / 1$ without eosinophilia, urea $7 \cdot 3 \mathrm{mmol} / \mathrm{l}$, creatinine $130 \mathrm{mmol} / 1 \stackrel{+}{ }$ creatinine clearance $29 \mathrm{ml} / \mathrm{min}$ and urine protein $0.78 \mathrm{~g} / 24 \mathrm{hr}$. His initial liver function tests showedbilirubin $55 \mu \mathrm{mol} / \mathrm{l}$, aspartate aminotransaminase $115 \mathrm{u} . / \mathrm{l}$, alanine aminotransaminase $146 \mathrm{u} . / \mathrm{l}$, alkaline phosphatase $2420 \mathrm{u}$./l and albumin $35 \mathrm{~g} / \mathrm{l}$. Hepatitis B surface antigen and hepatitis A antibody wege negative. Antinuclear factor, rheumatoid factor: smooth muscle antibody and antimitochondfalo antibody were negative. Intravenous cholangiograms and ultrasound scan of the liver and gall-bladdero showed no evidence of extra-hepatic biliary obstruc $\frac{0}{0}$ tion. Liver biopsy performed 11 days after admission $\varrho$ was normal when examined by light microscopy and $\overrightarrow{\overrightarrow{0}}$ electronmicroscopy using routine stains. No bar- 3 biturate was found in the serum on admission and urinary screen for porphyrins was negative.

He rapidly recovered consciousness with intra-o venous dextrose and $1 \mathrm{mg}$ glucagon intramuscularly. Bilirubin, aspartate and alanine amino-transamin- $\frac{0}{3}$ ases returned to normal levels by the fourth day and alkaline phosphatase was normal after the thirty-윽 seventh day. Both bullae gradually dried up over one month. Digoxin, frusemide and Slow-K were continued without any adverse effect. His diabetes was controlled by diet alone and he remains well on follow-up 3 months later.

\section{Discussion}

Glibenclamide is a potent and long-acting sul- - N phonylurea drug which is relatively free of adverse effects. By contrast, its predecessor chlorpropamideo has a number of adverse effects including intra- $\mathbb{D}$

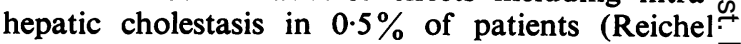
et al., 1960). Known adverse effects of these $2 \frac{7}{0}$ drugs are listed in Table 1. Glibenclamide has been $\frac{\bar{\Phi}}{\mathrm{D}}$ reported to cause transient skin rashes and slight $\stackrel{\odot}{\odot}$ 
TABLE 1. Known adverse effects of chlorpropamide and glibenclamide

\begin{tabular}{|c|c|}
\hline Chlorpropamide & Glibenclamide \\
\hline $\begin{array}{l}\text { Dermatological adverse effects }(1) \\
\text { Stevens-Johnson syndrome } \\
\text { Exfoliative dermatitis } \\
\text { Urticaria } \\
\text { Photodermatitis } \\
\text { Erythema nodosum } \\
\text { Papular and purpuric rashes } \\
\text { Alopecia areata } \\
\text { Generalized pruritus }\end{array}$ & $\begin{array}{l}\text { Hypoglycaemia }(10,11) \\
\text { Transient skin rashes }(12) \\
\text { Transient elevated aspartate and alanine aminotransaminases } \\
\quad(12,13) \\
\text { Minor gastrointestinal disturbances }(13) \\
\text { Generalized hypersensitivity visceral arteritis (14) } \\
\text { Nocturia (15) }\end{array}$ \\
\hline $\begin{array}{l}\text { Haematological adverse effects }(1) \\
\text { Aplastic anaemia } \\
\text { Agranulocytosis } \\
\text { Pancytopenia } \\
\text { Leucopenia } \\
\text { Thrombocytopenia } \\
\text { Red cell aplasia }(2) \\
\text { Immune haemolytic anaemia }\end{array}$ & \\
\hline $\begin{array}{l}\text { Hepatic adverse effects (1) } \\
\text { Cholestasis } \\
\text { Hepatitis } \\
\text { Granulomatus hepatitis (3) }\end{array}$ & \\
\hline $\begin{array}{l}\text { Miscellaneous adverse effects }(1) \\
\text { Hypoglycaemia } \\
\text { Alcoholic flushing } \\
\text { Diarrhoea } \\
\text { Inappropriate secretion of antidiuretic hormone }(4) \\
\text { Neonatal hypoglycaemia in infant of diabetic mother }(5) \\
\text { Pulmonary eosinophilia }(6) \\
\text { Possible increased incidence of myocardial infarction }(7,8) \\
\text { Anaphylaxis }(9)\end{array}$ & \\
\hline
\end{tabular}
1. Harris, 1971
2. Recker and Hynes, 1969
3. Powell and Howells, 1966
4. Weissman, Shenkman and Gregerman, 1971
5. Zucker and Simon, 1968.
6. Bell, 1964
7. Boyle et al., 1972

\author{
8. Hadden, Montgomery and Weaver, 1972 \\ 9. Ravid, Rubinstein and Cabili, 1971 \\ 10. Gottesbüren et al., 1970 \\ 11. Sillence and Court, 1975, \\ 12. O'Sullivan and Cashman, 1970 \\ 13. Burns, 1969 \\ 14. Clarke et al., 1974 \\ 15. Shaw, Bloom, and Bulpitt, 1977
}

elevation of aspartate and alanine aminotransaminases which are reversible without alteration to dosage (Burns, 1969; O'Sullivan and Cashman, 1970). It is also known to cause minor gastrointestinal disturbances (Burns, 1969), hypoglycaemia (Sillence and Court, 1975), which can be fatal especially in the elderly (Gottesbüren et al., 1970) and nocturia (Shaw, Bloom and Bulpitt, 1977). In one patient glibenclamide therapy was associated with a severe generalized hypersensitivity reaction resulting in fatal toxic erythema, cholestasis, eosinophilia and renal failure (Clarke et al., 1974). Post-mortem revealed a necrotizing angiitis with associated granulomatous changes in the spleen and kidneys.

The combination of reversible intrahepatic cholestasis and cutaneous bullae due to glibenclamide has not previously been recorded. In this patient the probable diagnosis of drug-induced intrahepatic cholestasis was determined by exclusion of extrahepatic biliary obstruction, viral hepatitis and primary liver disease. The cholestasis cleared within 5 weeks of glibenclamide withdrawal, whilst other drug therapy was continued. It was felt that rechallenge with glibenclamide might carry a risk and was therefore unethical, especially as the patient did not require an oral hypoglycaemic drug to control his diabetes mellitus.

The two cutaneous bullae resembled those occasionally produced by barbiturate poisoning or seen in porphyria cutanea tarda. However, both these diagnoses were excluded and as no further bullae have appeared they too were probably an adverse reaction to glibenclamide therapy.

The mechanism of glibenclamide-induced intrahepatic cholestasis and cutaneous bullae is uncertain, although a hypersensitivity reaction in association 
with toxic erythema and cholestasis was reported in a fatal case (Clarke et al., 1974). It has been suggested that a hypersensitivity reaction would account for chlorpropamide-induced intrahepatic cholestasis (Friedman, 1962). However, there was no firm evidence to support a hypersensitivity reaction in the present patient who had been on a standard dose of glibenclamide for 17 months before these 2 adverse effects developed.

In conclusion, attention should be drawn to the possibility of transient reversible intrahepatic cholestasis and cutaneous bullae induced by glibenclamide in a diabetic patient who presented with hypoglycaemic coma. All these adverse effects disappeared after the withdrawal of glibenclamide.

\section{References}

Aumüller, W., Bander, A., Heerdt, R., Muth, K., Pfaff, W., Schmidt, F.H., Weber, H. \& Weyer, R. (1966) A powerful new oral antidiabetic agent. ArzneimittelForschung, 16, 1640.

Bell, R.J.M. (1964) Pulmonary infiltration with eosinophils caused by chlorpropamide. Lancet, i, 1249.

Boyle, D., Bhatia, S.K., Hadden, D.R., Montgomery, D.A.D. \& WEAVER, J.A. (1972) Ischaemic heart-disease in diabetics: A prospective study. Lancet, i, 338.

BuRNs, F.H. (1969) Clinical experience with glibenclamide, a new hypoglycaemic agent. Medical Journal of Australia, 2, 436.

Clarke, B.F., Campbell, I.W., Ewing, D.J., Beverige, G.W. \& MACDonALD, M.K. (1974) Generalised hypersensitivity reaction and visceral arteritis with fatal outcome during glibenclamide therapy. Diabetes, 23, 739.

Friedman, A. (1962) Hepatic function of diabetic patients on chlorpropamide. Medical Annals of the District of Columbia, 31, 447.

GotTesbüren, H., Gerdes, H., Littmann, K.P. \& Martiniอ̊ I.G.A. (1970) Severe hypoglycaemia after glibenclamide? Lancet, ii, 576.

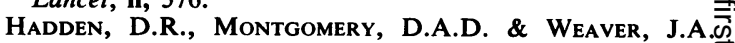
(1972) Myocardial infarction in maturity onset diabetics:A retrospective study. Lancet, i, 335.

HARRIS, E.L. (1971) Adverse reactions to oral antidiabetic agents. British Medical Journal, 3, 29.

O'Sullivan, D.J. \& Cashman, W.F. (1970) Blood glucose variations and clinical experiences with glibenclamide in diabetes mellitus. British Medical Journal, 2, 572.

Powell, T. \& Howells, L. (1966) Diabetes mellitus treatedwith chlorpropamide and tolbutamide: A four-year. clinical study. Diabetes, 15, 269.

Ravid, M., Rubinstein, E. \& CABILI, S. (1971) Anaphylactic reaction to chlorpropamide. British Medical Journal, $3 \frac{\mathrm{g}}{0}$ 162.

RECKER, R.R. \& HyNes, H.E. (1969) Pure red blood cell aplasia associated with chlorpropamide therapy: patientior summary and review of the literature. Archives of Internal. Medicine, 123, 445.

Reichel, J., Goldberg, S.B., Ellenberg, M. \& SchaffNer, F. (1960) Intrahepatic cholestasis following administration of chlorpropamide: report of a case with electron micro- $+\vec{A}$ scopic observations. American Journal of Medicine, 28,음 654.

ShaW, K.M., Bloom, A. \& BulpitT, C.J. (1977) Glibenclamide and nocturia. British Medical Journal, 1, 1415.

SillenCE, D.O. \& CoURT, J.M. (1975) Glibenclamideinduced hypoglycaemia. British Medical Journal, 3, 490.-

Weissman, P.N., Shenkman, L. \& Gregerman, R.I. (198) Chlorpropamide hyponatremia: drug induced inappropriale antidiuretic hormone activity. New England Journal of Medicine, 284, 65.

ZuCKer, P. \& Simon, G. (1968) Prolonged symptomatic neonatal hypoglycemia associated with maternal chlorpropamide therapy. Pediatrics, 42, 824. 